\title{
Karakterisasi Genetik Kambing Gembrong dari Karangasem Bali Menggunakan DNA Mikrosatelit
}

\section{Genetics Characteristic of Gembrong Goat from Karangasem Bali Using Microsatellite DNA}

\author{
I Ketut Puja* dan I Nyoman Sulabda
}

Fakultas Kedokteran Hewan Universitas Udayana, Jl. PB. Sudirman, Denpasar Bali E-mail: asubali@hotmail.com*Penulis untuk korespondensi

\begin{abstract}
The present study was undertaken with primary objective to characterize of Gembrong goat breeds. It is essential to characterize the germplasm for intragenetic variability, which will help in planning for conservation strategy as well as genetic improvement. DNA Genome was isolated from hairs. Nine microsatellite were amflified by PCR. PCR product were run on $6 \%$ bis-Acrylamide gel in automated DNA sequencer. Flourescent signals from the dye-labeled microsatellite were detecting using STRand software. The result show that all markers (INRA005, INRA063, INRA023, ILSTS19, ILSTS87, SRCRSP8, MAF65, OarFCB20, and McM547) successfully amplified in Gembrong goat microsatellite loci. The number of alleles per locus ranged from 1 (INRA005) to 4 (ILSTS87). All the microsatellites investigated were found to be highly polymorphic, except INRA063. In total, 23 alleles were observed for the 9 microsatellite loci. The allele sizes ranged from 99 bp (OarFCB20) to 240bp (SRCRSP8). The study can be extended to include large many microsatellites in different chromosome location to validate the results.
\end{abstract}

Key words: genetics characteristic, Gembrong Goat, DNA mikrosatellite

Diterima: 25 Agustus 2008, disetujui: 19 Desember 2008

\section{Pendahuluan}

Kambing merupakan hewan piara yang pertama kali didomestikasi (Boyazoglu et al., 2005) atau paling tidak setelah anjing. Kambing merupakan ternak piaraan yang tersebar paling luas di daerah tropis (Mandonnet et al., 2001). Distribusinya yang luas sebagian dijelaskan karena kemampuannya untuk hidup terus dan subur di lingkungan yang keras. Di negara yang sedang berkembang, kambing mulai popular diternakkan bahkan telah menjadi sumber cadangan ekonomi pada negara berkembang (Sahlu dan Goetsch, 2005). Sekarang ini, pemeliharaan kambing telah meningkat dengan pesat mengikuti kebutuhan pasar (Mowlen, 2005).
Di Indonesia populasi kambing sangat besar dan tersebar di seluruh wilayah. Peternakan kambing berperan sangat penting dan strategis dan mempunyai prospek yang baik di dalam penyediaan protein hewani maupun sumber devisa Negara.

Di Indonesia terdapat beberapa rumpun ternak kambing lokal yang hanya terdapat di daerah tertentu seperti Kambing Gembrong berasal dari Bali khususnya di pantai timur Bali, kambing Kosta terdapat di Kabupaten Pandeglang dan Kambing Marica berasal dari Sulawesi Selatan. Keragaman plasma nutfah ini merupakan bahan dasar bagi pemuliaan ternak kambing dikemudian hari. Namun, beberapa diantara kambing tersebut ada yang terancam punah yaitu kambing Gembrong. Karena itu, kambing tesebut perlu dilestarikan meskipun belum diketahui keistimewaannya. 
Kambing Gembrong selain penghasil daging, bulunya yang panjang digunakan untuk memancing ikan di laut. Kambing yang unik ini nyaris punah dan akan menambah daftar sejumlah kekayaan hayati Indonesia yang bernasib sama atau hampir lenyap dari bumi. Bila dibiarkan akan makin banyak kekayaan hayati yang tidak terurus sehingga kita kehilangan kekayaan genetik. Risiko punahnya tipe kambing Gembrong karena pembiakan yang tidak terkendali dan perkawinan silang yang sembarangan.

Karakterisasi genetik merupakan langkah awal di dalam program konservasi satwa langka. Karakter genetik tersebut akan dapat digunakan sebagai pedoman di dalam mengambil keputusan untuk menentukan keunikan dari bangsa hewan tersebut. Sehingga hal tersebut merupakan prioritas dalam tujuan konservasi.

Dalam memahami karakter genetik suatu bangsa ternak, telah banyak metode yang digunakan untuk mengidentifikasi suatu spesies. Awalnya identifikasi didasarkan pada kesamaan secara morfologi dan sekarang telah ditingkatkan pada analisis molekular. Gour et al., (2005) telah menggunakan analisis molekular yaitu mikrosatelit DNA untuk karakterisasi bangsa kambing di India. Lebih lanjut, dijelaskan bahwa analisis ini memberikan hasil yang sangat baik untuk penentuan bangsa.

Microsatelite atau dikenal juga dengan short tandem repeats adalah urutan nukleotida pendek secara berurutan dalam genom eukariota. Pemberian nama ini didasarkan pada kandungan nukleotida yang biasanya terdiri dari 1 sampai 5 pasang. Mikrosatelit mempunyai motif urutan sederhana dan panjangnya tidak lebih dari 6 pasang basa. Motif urutan terulang yang sering dijumpai pada genom eukariota adalah $(\mathrm{dC}-\mathrm{dA})_{\mathrm{n}}-(\mathrm{dC}-$ dA) n. Mikrosatelit ini telah diketahui sangat polimorfik pada suatu populasi, karena keragaman jumlah nukleotida yang terulang (Litt dan Luty, 1989; Zacj et al., 1997). Penyebarannya sangat acak di dalam genom (Luty et al., 1990), hal ini menyebabkan mikrosatelit sangat berguna untuk pemetaan genom. Saat ini mikrosatelit merupakan petanda genetik yang banyak dipilih untuk keperluan pemeriksaan molekular. Beberapa pemeriksaan molekular yang menggunakan mkrosatelit diantaranya untuk analisis struktur populasi (Arora dan Bathia, 2004), memperkirakan keragaman genetik dan inbreeding (Mateus et al., 2004; Gour et al., 2005; Iamartino et al., 2005; Fatima et al., 2008; Sodhi et al., 2008), catatan silsilah (Talbot et al., 1996; Luikart et al., 1999), dan identitas individu (Maudet et al., 2004; Dalvit, 2008).

\section{Metode Penelitian}

Untuk isolasi DNA digunakan sampel bulu kambing yang diambil dari 26 ekor kambing dengan cara mencabut bulu pada bagian paha belakang. Jumlah sampel bulu pada setiap ekor kambing berjumlah paling sedikit 20 helai dan yang mengandung akar (folikel bulu).

Sebanyak sembilan primers mikrosatelit digunakan dalam penelitian ini. Primer dipilih dari marker mikrosatelite yang disarankan oleh FAO/ISAG (http://www.fao.org/dad-is). Reaksi amplifikasi pada PCR dilakukan pada PCT 100 (MJ Research, Inc, Watertown, Mass,USA. Protokol PCR diprogram dengan kondisi pra denaturasi $\left(94^{\circ} \mathrm{C}\right)$ selama 5 menit; denaturasi $\left(94^{\circ} \mathrm{C}\right)$ selama 45 detik; annealing $\left(52-60^{\circ} \mathrm{C}\right)$ selama 45 detik; dan elongasi $\left(72^{\circ} \mathrm{C}\right)$ selama 45 detik. PCR dilakukan sebanyak 30 siklus. Pada bagian akhir dilakukan elongasi $\left(72^{\circ} \mathrm{C}\right)$ selama 10 menit.

Hasil amplifikasi dipisahkan dengan gel bis-Acrylamide $6 \%$ pada mesin DNA sequencer otomatis (ABI Prism 377 DNA Sequencer-PE Biosystem, Foster City, CA USA). Hasil divisualisasi memakai petanda floresensi dari mikrosatelit yang dilabel pewarna floresen. Hasil akan dibaca STRand software VERSI 2.2.39.

\section{Hasil dan Pembahasan}

Hasil analisis mikrosatelite pada kambing Gembrong dengan mengacu pada jumlah allel dan ukuran allel dapat dilihat pada Tabel 1. Kesembilan marker mikrosatelit 
teramplifikasi dengan baik pada kambing Gembrong.

Mikrosatelit INRA005 berlokasi pada kromosom no 12. Pada kambing Gembrong, lokus INRA005 mempunyai 2 alel berbeda. Alel 1 berukuran 115 bp dan allel 2 berukuran 117 bp. Alel 1 terdeteksi 17 homozigot dan 9 heterozigot. Allel 2 terdeteksi pada 9 sampel heterozigot. Vaiman et al., (1996) melaporkan bahwa ukuran lokus ini adalah 139 - 147 bp.

Mikrosatelit INRA023 berlokasi pada kromosom no.3. Pada kambing Gembrong, lokus INRA023 mempunyai 4 alel berbeda. Alel 1 berukuran 195 bp, allel 2 berukuran 197 bp, allel 3 berukuran $197 \mathrm{bp}$, dan allel 4 berukuran 209 bp. Allel 1 terdeteksi 11 heterozigot dan 9 homozigot. Allel 2 terdeteksi pada 7 sampel heterozigot. Allel 3 terdeteksi pada 4 heterozigot, dan allel 4 terdeteksi 10 heterozigot.

Mikrostelit INRA063 berlokasi pada kromosom no 16. Pada kambing Gembrong, lokus INRA063 mempunyai 1 allel berukuran 175 bp. Saitbekova et al., (1999) melaporkan bahwa lokus INRA063 yang merupakan mikrosatelit dari sapi teramplifikasi dengan baik dengan jumlah allel terdeteksi sebanyak 19 dengan ukuran 156-200 bp.

Mikrosatelite ILSTS19 berlokasi pada kromosom no.25. Pada kambing Gembrong, lokus ini mempunyai 3 allel berbeda, yaitu allel 1 berukuran $152 \mathrm{bp}$, allel 2 berukuran $154 \mathrm{bp}$, dan allel 3 berukuran 156 bp. Allel 1 terdeteksi 13 heterozigot, allel 2 terdeteksi 9 heterozigot dan 2 homozigot, dan allel 3 terdeteksi 12 heterozigot dan 7 homozigot. Kemp et al., (1995) melaporkan bahwa marker mikrosatelit ini sangat polimorfik pada kambing dengan ukuran mikrosatelitnya adalah $153 \mathrm{bp}$.

Mikrostelit ILSTS87 berlokasi pada kromosom no 6. Pada kambing Gembrong, lokus ILSTS87 mempunyai 4 allel. Allel 1 berukuran $141 \mathrm{bp}$ dan terdeteksi 8 heterozigot, allel 2 berukuran 143 bp dan terdeteksi 1heterozigot, allel 3 berkuran 145 bp dan terdeteksi 15 homozigot dan 12 heterozigot, dan allel 4 terdeteksi 1 homozigot dan 5 heterozigot. Allel 4 ini berukuran 151 bp. Kemp et al., (1995) melaporkan bahwa lokus ini sangat polimorfik pada kambing dan domba serta allel ini berukuran 128 bp. Gortari et al.,
(1997) melaporkan bahwa pada domba lokus ini berukuran 143-163 bp.

Mikrostelit SRCRSP8, lokasinya belum diketahui secara pasti pada kromosom. Pada kambing Gembrong, lokus SRCRSP8 mempunyai 2 allel. Allel 1 berukuran 230 bp dan terdeteksi 4 heterozigot dan 22 homozigot, allel 2 berukuran 240 bp dan terdeteksi 4 heterozigot. Saitbekova et al., (1999) melaporkan bahwa lokus SRCRSP8 teramplifikasi dengan baik dengan jumlah allel terdeteksi sebanyak 13 dengan ukuran 213-243 bp.

Mikrostelit OARFCB20 berlokasi pada kromosom no. 2. Pada kambing Gembrong, lokus OARFCB20 mempunyai 2 allel. Allel 1 berukuran 99 bp dan terdeteksi 1 heterozigot, allel 2 berukuran 101 bp dan terdeteksi 1 heterozigot dan 25 homozigot. Saitbekova et al., (1999) melaporkan bahwa lokus OarFCB20 teramplifikasi dengan baik dengan jumlah allel terdeteksi sebanyak 15 dengan ukuran 88-120 bp.

Mikrostelit MAF65 berlokasi pada kromosom no 4. Pada kambing Gembrong, lokus MAF65 mempunyai 3 allel. Allel 1 berukuran 119 bp dan terdeteksi 15 heterozigot dan 5 homozigot, allel 2 berukuran 127 bp dan terdeteksi 8 heterozigot, allel 3 berukuran 139 bp dan terdeteksi 9 heterozigot dan 4 homozigot. Saitbekova et al., (1999) melaporkan bahwa lokus MAF65 teramplifikasi dengan baik dengan jumlah allel terdeteksi sebanyak 9 dengan ukuran 123-141 bp.

Mikrostelit McM527 berlokasi pada kromosom no. 5. Pada kambing Gembrong, lokus McM527 mempunyai 2 allel. Allel 1 berukuran $156 \mathrm{bp}$ dan terdeteksi 11 heterozigot dan 12 homozigot. Allel 2 berukuran 158 bp dan terdeteksi 11 heterozigot dan 2 homozigot. Mainguy et al., (2005) melaporkan bahwa lokus ini yang dikembangkan pada domba teramplifikasi pada kambing dengan ukuran allelnya adalah162-168 bp.

Jumlah keseluruhan allel yang diamati pada analisis ini adalah 23 allel. Jumlah allel perlokus bervariasi dari 1 (INRA063) sampai 4 (ILSTS87). Sebanyak 9 dari 10 mikrosatelite marker yang digunakan bersifat polimorfik. 
Tabel 2. Allel Microsatellite, jumlah alel dan ukuran allel

\begin{tabular}{lcc}
\hline \hline \multicolumn{1}{c}{ Marker Mikrosatelit } & Jumlah Alel & Ukuran Alel \\
\hline \hline INRA055 & 2 & $115-117$ \\
INRA023 & 4 & $195-209$ \\
INRA063 & 1 & 175 \\
ILSTS19 & 3 & $152-156$ \\
ILSTS87 & 4 & $141-151$ \\
SRCRSP8 & 2 & $230-240$ \\
OarFCB20 & 2 & $99-101$ \\
MAF65 & 3 & $119-139$ \\
McM527 & 2 & $156-158$ \\
\hline \hline
\end{tabular}

\section{Kesimpulan dan Saran}

\section{Kesimpulan}

Mikrosatelit yang dikembangkan pada sapi dan domba dapat teramplifikasi dengan baik pada kambing Gembrong. Jumlah keseluruhan allel yang diamati pada analisis ini adalah 23 allel. Jumlah allel perlokus bervariasi dari 1 (INRA063) sampai 4 (ILSTS87). Sebanyak 9 dari 10 mikrosatelite marker yang digunakan bersifat polimorfik dan satu lokus adalah monomorfik (INRA063). Profil mikrosatelit pada kambing Gembrong ini dapat dipakai sebagai identitas genetik kambing Gembrong.

\section{Saran}

Perlu dilakukan penelitian lanjut dengan mengunakan lokus mikrosatelit pada kromosom berbeda untuk menentukan struktur genetik kambing Gembrong.

\section{Ucapan Terima Kasih}

Terima kasih disampaikan kepada Direktorat Jendral Pendidikan Tinggi, Departemen Pendidikan Nasional melalui Proyek Penelitian Ilmu Pengetahuan Dasar dengan Surat Perjanjian Pelaksanaan Penelitian No. 045/SP2H/PP/DP2M/III/207 Tanggal 29 Maret 2007.

\section{Daftar Pustaka}

Arora, R. and Bhatia, S. 2004. Genetic Structure of Muzzafarnagri Sheep Based on Microsatellite Analysis. Small Rum. Res. 54: 227-230.
Boyazoglu, J., Hatziminaoglou, I. and Morand-Fer, P. 2005. The Role of The Goat in Society: Past, Present and Perspectives for the Future. Small Rum. Res. 60: 13-23.

Dalvit, C., Saccà, E., Cassandro, M., Gervaso, M., Pastore, E. and Piasentier, E. 2008. Genetic Diversity and Variability in Alpine Sheep Breeds. Small Rum. Res. 80:45-51.

Fatima, S., Bhong, C.D., Rank, D.N. and Joshi, C.G. 2008. Genetic Variability and Bottleneck Studies in Zalawadi, Gohilwadi and Surti Goat Breeds of Gujarat (India) using Microsatellites. Small Rum. Res. 77: 58-64.

Gortari, M.J., Freking, B.A., Kappes, S.M., Leymaster, K.A., Crawford, A.M., Stone, R.T. and Beattie, C.W. 1997. Extensive Genomic Conservation of Cattle Microsatellite Heterozygosity in Sheep. Animal Genetics 28: 274-290.

Gour, D.S., Malik, G., Ahlawat, S.P.S., Panday, E.K., Sharma, R., Gupta, N., Gupta, S.C., Bisen, P.S. and Kumar, D. 2005. Analysis of Genetic Structure of Jamunapari Goats by Microsatellite Markers.

Iamartino, D., Bruzzone, A., Lanza, A., Blasi, M. and Pilla, F. 2005. Genetic Diversity of Southern Italian Goat Populations Assessed by Microsatellite Markers. Small Rum. Res. 57: 249-255.

Kemp, S.J., Hishida, O., Wambugu, J., Rink, A., Longeri, M.L., Ma, R.Z., Da, Y., Lewin, H.A., Barendse, W. and Teale, A.J. 1995. A Panel of Polymorphic Bovine, Ovine and Caprine Microsatellite Markers. Animal Genetics 26: 299-306.

Litt, M. and Lutty, J.A. 1989. A Hyper Variable Microsatellite Revealed by in vitro Amplification of a Dinucleotide Repeat Within the Cardiac Muscle Actin Gene. American J. of Human Genetics 44: 397-401. c.f.: Genomics 10 (1994): 645-660. 
Luikart, G., Biju-Duval, M.P., Ertugrul, O., Zagdsuren, Y., Maudet, C. and Taberlet, P. 1999. Power of 22 Microsatellite Markers in Fluorescent Multiplexes for Parentage Testing in Goats (Capra Hircus). Anim Genet. 30: 431-438.

Luty, J.A., Guo, Z., Willard, H.F., Ledbetter, D.H., Ledbetter, S. and Litt, M. 1990. Five Polymorphic Microsatellite VNTRs on the Human X Chromosome. Am. J. Hum. Genet. 46: 776-783.

Mainguy, J., Amy, S., Llewellyn, Worley, K., Steeve, D.C. and Coltman, D.W. 2005. Characterization of 29 Polymorphic Artiodactyl Microsatellite Markers for The Mountain Goat (Oreamnos Americanus). Mol. Ecol. Notes. 5: 809-811.

Mandonnet, N., Aumont, G., Flery, J., Arquet, R., Varo, H., Gruner, L., Bouix, J. and Khang, J.V. 2001. Assessment of Genetic Variability of Resistance to Gastrointestinal Nematode Parasites in Creole Goats in The Humid Tropics. J. Anim Sci.79: 1706-1712.

Mateus, J.C., Penedo, M.C., Alves, V.C., Ramos, M. and Rangel-Figueiredo, T. 2004. Genetic Diversity and Differentiation in Portuguese Cattle Breeds using Microsatellites. Anim. Genet. 35: 106-113.

Maudet, C., Beja-pereira, A., Zeyl, E., Nagash, H., Kence, A., Ozüt, D., Biju-duval, S., Boolormaa, S., Coltman, D.W., Taberlet, P. and Luikart, G. 2004. A Standard Set of Polymorphic Microsatellites for Threatened Mountain Ungulates (Caprini, Artiodactyla). Molecular Ecology Notes 4: 49-55.
Mowlen, S. 2005. Marketing Goat Dairy Produce in The UK. Small Ruminant Research 60: 207-213.

Sahlu, T. and Goetsch, A.1. 2005. A Foresight on Goat Research. Small Ruminant Research 60: 7-12.

Saitbekova, N., Gaillard, C., Obexer-Ruff, G. and Dolf, G. 1999. Genetic Diversity in Swiss Goat Breeds on Microsatellite Analysis. Animal Genetics 30: 36-41.

Sodhi M, Mukesh M, Prakash B, Ahlawat PS, and Sobti RC, 2008. Microsatellite DNA typing for assessment of genetic variability in Tharparkar breed of Indian zebu (Bos indicus) cattle, a major breed of Rajasthan. J. of Genetics 85 (3): 165-170.

Talbot, J., Haigh, J. and Plante, Y. 1996. A Parentage Evaluation Test in North American Elk (Wapiti) using Microsatellites of Ovine and Bovine Origin. Anim. Genet. 27: 117-119.

Vaiman, D., Schibler, L., Bourgeois, F., Oustry, F., Amigues, Y. and Cribiu, E.P. 1996. A Genetic Linkage Map of The Male Goat Genome. Genetics 144: 279-305.

Zajc, I., Mellersh, C.S. and Sampson, J. 1997. Variability of Canine Microsatellites Within and Between Different dog Breeds. Mamm. Genome 8: 182-185. 